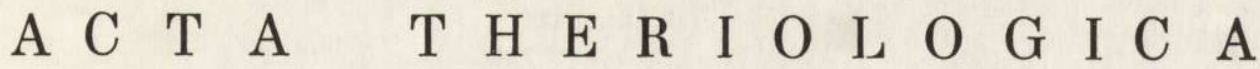

VOL. 19, 20: $291-300$.

BIAŁOWIEŻA

September, 1974

Jan K A Ł U Z I N S K I

\section{The Occurrence and Distribution of Field Ecotype of Roe-deer in Poland}

\author{
[With 1 Table \& 3 Figs.]
}

\begin{abstract}
On the basis of inquiries the analysis of distribution and numbers of "field " roe-deer was carried out followed by drawing a map of its occurrence in Poland. It was found that in the years 1966-1970 approximately 30 thousand of field roe-deer lived in the whole area of the country. The relationship between the occurrence of the field ecotype of roe-deer and such factors as forestage, agriculture and climate was established.
\end{abstract}

\section{INTRODUCTION}

Environmental changes caused by the activity of man reduce or even totally eliminate the occurrence of several animal species. On the other hand, some species find almost ideal conditions of life in the altered environment ( $\mathrm{S} \mathrm{z} \mathrm{c} \mathrm{z} \mathrm{e} \mathrm{r} \mathrm{bin} \mathrm{ski,} \mathrm{1964).} \mathrm{The} \mathrm{roe-deer} \mathrm{belong} \mathrm{to} \mathrm{the} \mathrm{latter}$ species as witnessed by a considerable increase in their number in forests (Pielowski, 1970), and by taking into possession new habitats such as cultivated fields. The augmented number of these animals is directly related to the formation of cultured landscape since in the-primeval conditions the roe-deer occurred rarely (M ülle r-U s ing, 1957, 1962; Szczerbiński, 1964).

The accurate data on the field ecotype of the roe-deer are lacking in Polish literature. The roe-deer living in the fields of Poznan and Lwów provinces are mentioned by Schechtel (1929). On the other hand, Meisnerowski (1959) and Pielowski (1970) have already distinguished two principal ecotypes: "forest « and "field " roe-deer. They differ in several traits and characteristics, but mainly in the site of living ( $\mathrm{P}$ i e l o w s k i, 1970). The "field " roe-deer occurs in open cultivated fields. It avoids forests and even in the case of danger it escapes in the direction of open fields. The permanent living in fields has caused several 
adaptative changes. A physiological adaptation of the field ecotype depends on feeding mainly with ground layer plants, such as green parts of cultivated plants (Pielowski, 1970), while according to B u be nik (1959) the principal food of roe-deer consists of twigs of trees and shrubs, which constitute approximately $60 \%$ of the total consumed food.

Physiology of digestion has also been altered since the three or four-phase cycle of feeding activity, characteristic for forest roe-deer is not

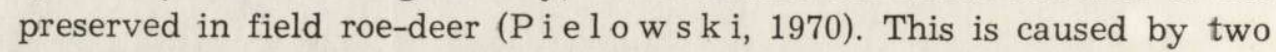
main factors: time of feeding of field roe-deer depends in some periods on the presence of men working in the fields, and moreover, the whole daily dycle occurs in principle in one site which at the same time is a feeding ground and place for rest. Hence field roe-deer does not move systematically from the daily habitat to the feeding ground and in reverse direction.

Among ecological differences cleary discernible between both ecotypes a characteristic spatial structure of their population should be emphasized. From October to the first days of May field roe-deer lives in organized herds, while forest roe-deer at these seasons lives singly or in small groups. Herds of field roe-deer can count a dozen to several dozens of individuals and occupy permanent districts. One herd lives usually in a range of approximately 200 ha in area (P i e low ski, 1970) and it has established directions of escape in case of danger.

Hence we know certain physiological and ecological traits differing these two roe-deer ecotypes. At the same time, however, we are lacking basic data on the number and distribution of field roe-deer in Poland. This ecotype is known to occur also in Denmark, Czechoslovakia, two German countries and in Hungary ( $\mathrm{Pielowski,1970).} \mathrm{The} \mathrm{present}$ study was aimed at the investigation of the number and distribution in Poland of the field ecotype of roe-deer, Capreolus capreolus L in n a e us, 1758. From theoretical point of view this is particularly interesting since we have a chance of studying the process of separation and fixation of a new roe-deer ecotype, with its all ecological aspects.

\section{METHODS}

The data on the occurrence of field roe-deer in Poland were accumulated by the method of inquiries. The questionnaires were sent to the District Hunting Councils all over the country, and were accompanied by the explanation of importance of the inquiry and description of the criteria essential for distinguishing field and forest roe-deer. The District Councils should know the numbers of field roe-deer from stock-taking of the game carried out every year on the hunting grounds by individual Hunting Circles. Due to this it was possible to 
accumulate the data also for previous years. Of course the accuracy of the stock-taking depends on the discernment of a particular Board of the Hunting Association. Usually the collected data are also sent to the People's District Councils and the Central Statistical Office. It must be admitted that the material obtained in such way is not based on uniform scientific methods. However, the District Hunting Councils having a direct contact with the users of hunting areas and having discernment on the number of game occurring in the district seem to be the most competent bodies to answer the questionnaire. If required the collected material was additionally defined more accurately by further correspondence or by direct interviews with persons regarded as experts on the problem of field roe-deer in particular regions of the country.

The inquiries included the years 1966-1970 in the whole area of Poland. Out of 308 questionnaires sent 257 were returned, this corres-

Table 1

Numbers of field roe-deer in Poland according to Provinces.

\begin{tabular}{|c|c|c|c|c|c|c|c|}
\hline \multirow{2}{*}{ Province } & \multicolumn{2}{|c|}{ Questionnaires } & \multicolumn{5}{|c|}{ No. of roe-deer in the years } \\
\hline & Sent & Received & 1966 & 1967 & 1968 & 1969 & 1970 \\
\hline Białystok & 16 & 13 & - & - & - & - & - \\
\hline Bydgoszcz & 20 & 16 & 3341 & 4077 & 3774 & 4195 & 2778 \\
\hline Gdańsk & 13 & 10 & 1592 & 1727. & 1710 & 1647 & 1322 \\
\hline Katowice & 15 & 12 & 415 & 633 & 780 & 516 & 542 \\
\hline Kielce & 16 & 15 & 266 & 331 & 378 & 441 & 382 \\
\hline Kraków & 17 & 12 & 118 & 161 & 196 & 327 & 227 \\
\hline Koszalin & 13 & 12 & 296 & 304 & 375 & 432 & 263 \\
\hline Lublin & 17 & 15 & 77 & 111 & 139 & 115 & 99 \\
\hline Łódź & 16 & 16 & 809 & 837 & 925 & 1041 & 614 \\
\hline Opole & 14 & 13 & 1587 & 1719 & 1713 & 1953 & 2043 \\
\hline Olsztyn & 17 & 17 & 3022 & 3082 & 3481 & 3260 & 2066 \\
\hline Poznań & 28 & 23 & 6907 & 8414 & 8132 & 9651 & 6579 \\
\hline Rzeszów & 22 & 12 & 261 & 315 & 365 & 426 & 431 \\
\hline Szczeciń & 13 & 9 & 879 & 1337 & 1557 & 1526 & 1157 \\
\hline Warszawa & 28 & 27 & 1004 & 1348 & 1923 & 1957 & 1397 \\
\hline Wrocław & 27 & 23 & 1894 & 1831 & 1942 & 1335 & 2083 \\
\hline Zielona Góra & 16 & 11 & 1088 & 1194 & 1192 & 1234 & 1313 \\
\hline Poland & 308 & 257 & 23574 & 27421 & 28582 & 29056 & 23296 \\
\hline
\end{tabular}

ponding to approximately $84 \%$ of replies. The collected materials on the rumbers of field roe-deer were listed in accordance with provinces, and the data concerning the distribution of field roe-deer were plotted on the administration map of Poland.

\section{RESULTS}

Field roe-deer inhabits the whole area of Poland except Bialystok Province. The most numerous is in the Provinces of Gdańsk, Opole, 
Poznań, Bydgoszcz and Olsztyn (Table 1). Some doubts on the proper qualification of roe-deer to the field ecotype arised during analysis of data from some districts of Olsztyn Province. They are probably due to difficulties in the distinct separation of field and forest roe-deer which in periods live on the arable grounds, on account of typical mosaic structure of forests and fields in this region.

In the Provinces mentioned above more than $80 \%$ of districts is inhabited by field roe-deer. Moreover, other regions of Poland show an intermediate number of these animals: Provinces of Szczecin, Zielona Góra, Wrocław, Katowice, Łódź and Warszawa. The smallest number of field roe-deer is encountered in eastern Provinces (Table 1).

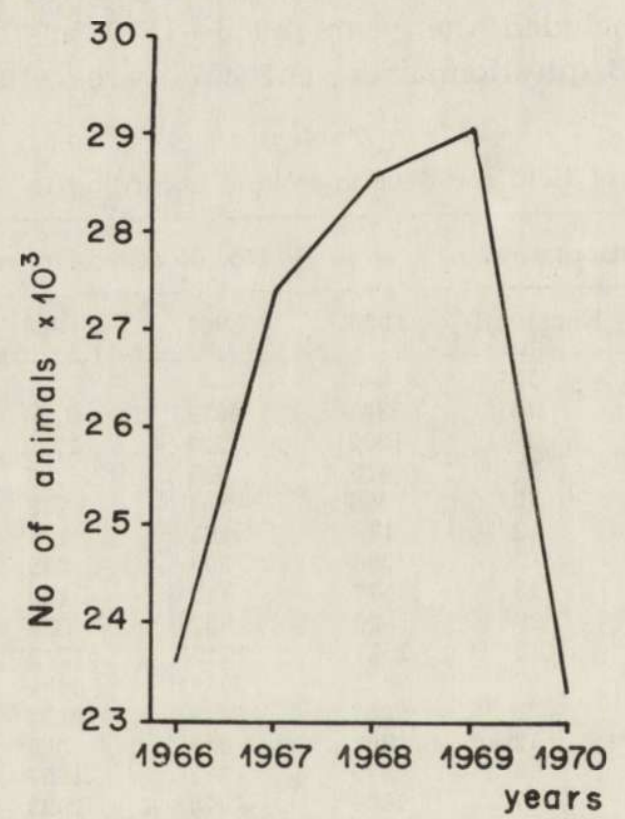

Fig. 1. Numbers of field roe-deer in Poland.

On the whole area of Poland the numbers of field roe-deer systematically increased during the period of studies. In 1969 approximately 30 thousand of field roe-deer lived in our country, this figure representing $10 \%$ of the total number of roe-deer in Poland. The values on the number of field roe-deer are treated as an approximation, since not all District Hunting Councils responded to the inquiry. The real numbers of the field ecotype of roe-deer are thus probably higher than reported in Table 1. Relatively high numbers in the years 1966-68 were reduced in the year 1969-1970 when very difficult winter conditions resulted in great losses in the population of field roe-deer (Fig, 1, Table 1). 
On the basis of analysis of distribution and numbers of field roe-deer in Poland four zones of its occurrence can be distinguished. The criterion for the separation of the first zone is uninterrupted continuation of districts, each of them being inhabited by at least 50 individuals of field roe-deer (Fig. 2). This number has been selected since according to the data of the Research Station of the Polish Hunting Association at Czempin it corresponds to $7-10$ herds of roe-deer observed during autumn and winter stock-taking. Such group of roe-deer cannot escape attention

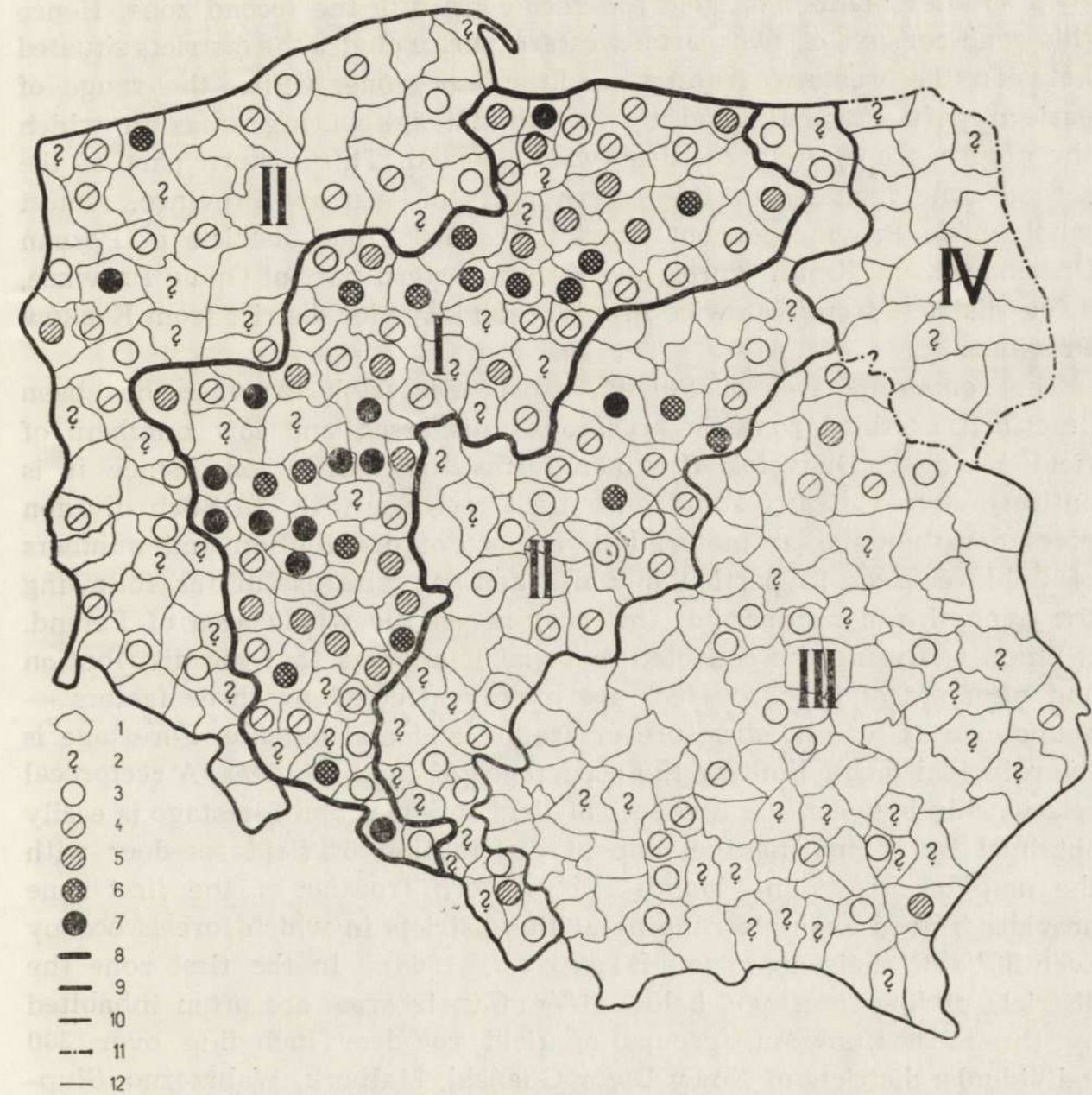

Fig. 2. Distribution of field roe-deer on the area of Poland in 1969.

1 - districts without field roe-deer; 2 - lack of data; 3 - numbers below 50 individuals per district; 4 - from 51 to 200 individuals; $5-$ from 201 to 350 individuals; $6-351-500$ individuals; $7-$ above 500 individuals; 8 - first zone, 9 - second zone, 10 - third zone, 11 - fourth zone, 12 - boundaries of districts. 
of a trained observer, and moreover it seems to be sufficiently numerous for a permanent population. The first zone includes the area of the following Provinces: Olsztyn, except districts Kętrzyn, Węgorzewo, Giżycko and Pisz; eastern part of Gdańsk Province; almost whole Bydgoszcz Province except districts Chojnice and Tuchola; district Złotów from Koszalin Province; large areas of the Provinces of Poznań and Wrocław, as well as western districts of Opole Province (Fig. 2).

The areas situated to East and West from the first zone and inhabited by a smaller number of field roe-deer constitute the second zone. Hence this zone consists of two parts: western part includes the districts situated between the western frontier and the first zone, while the range of eastern part was estimated by including neighbouring areas in which the occurrence of field roe-deer was reported. This eastern part of the second zone includes north-western parts of Warsaw Province, almost whole Łódź Province except district Radomsk, four districts of Poznań Province: Koło, Konin, Turek and Kalisz, eastern part of Opole Province, a few districts from Katowice Province, and Żywiec district from Kraków Province.

The remaining area of Poland, except Białystok Province, has been described as third zone on account of dispersed and low numbers of field roe-deer. Bialystok Province forms the fourth zone, since it is entirely devoid of any stand with field roe-deer (Fig. 2). Such division gives a rather similar material in respect of distribution and numbers of field roe-deer in particular zones and may be useful for following the dynamics of numbers of this ecotype on the whole area of Poland.

When analysing the collected material it appears that the distribution and numbers of field roe-deer are mainly affected by three factors abundance of forests, structure of arable land and climate. Forestage is the principal factor limiting the occurrence of field roe-deer. A reciprocal relationship between the numbers of field roe-deer and forestage is easily obtained by comparing the map of distribution of field roe-deer with the map of forests in Poland. The western frontier of the first zone provides a good example running at the districts in which forests occupy over $30 \%$ of their area (cf. Błaszy k, 1968). In the first zone the districts of low forestage, below $10 \%$ of their area, are often inhabited by the most numerous groups of field roe-deer including over 300 individuals: districts of Nowy Dwór Gdański, Malbork, Wąbrzeżno, Słupca, Wrocław, Nysa, Głubczyce and Racibórz (Fig. 2). In fact the whole first zone abounding in field roe-deer is characterized by a low forestage and high agricultural standard. The second zone is non uniform in respect of forestage: its western part belongs to the area of the highest forestage in Poland, and this factor is known to be responsible for the low numbers 
of field roe-deer. On the other hand, the eastern part of the second zone, and the whole third zone except Białystok and Rzeszów Provinces, have similar forestage as the first zone. In this part of Poland forestage exerts a less pronounced effect on the numbers of field roe-deer. It seems that in this case the population of this ecotype is limited by other factors, i.e., agriculture and climate. Climatic differences between western and eastern regions of our country are well known. In western areas of Poland snow persists for $40-50$ days in a year, while in eastern areas over 90 days ( $\mathrm{Schm} \mathrm{uck}, 1969)$. The effect of prolonged snow cover and other climatic factors related to winter is best illustrated by severe winter in $1969 / 70$ (Fig. 1). The structure of arable land is also very important for the numbers of field roe-deer. It is known that this ecotype lives in organized herds in the period from autumn till spring ( $\mathrm{Pi}$ elowski, 1969). Open fields devoid of plant cover provide to roe-deer easy observation of the terrain essential for security. This problem is particularly important in autumn when the fields are intensely penetrated by men

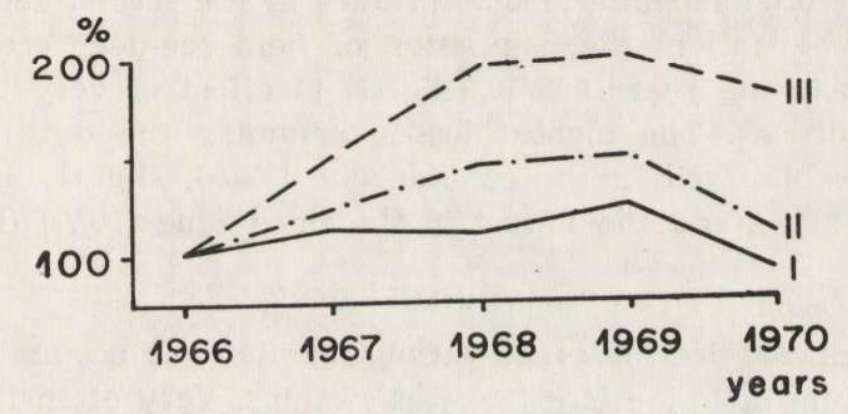

Fig. 3. Dynamic of numbers of field roe-deer in particular zones I - first, II second, III - third.

during agricultural measures, collection of root-crops and corn sowing. In this period field roe-deer have very limited possibilities of finding quiet sites. This is even more difficult in divided fields belonging to small farms. It is known that small fields dominate in the eastern part of Poland. Such Provinces as Lubiln, Kielce, Warszawa, Łódź and Rzeszów represent good examples (Statistical Yearbook of Agriculture, 1971).

The prevalence of small farms and rather difficult climatic conditions affect in a negative way the occurrence of field roe-deer in eastern regions of the country. In the fourth zone the negative effects of all factors, including structure of arable land, climate and forestage are so strong that hitherto in the whole area of Białystok Province not a single stand of field roe-deer has been ascertained (Fig. 1, Table 1). 
The collected data were employed to compute the numbers of field roe-deer falling for a definite area. It was found that for every 1000 ha of the area fall over 2 roe-deer of the field ecotype in the first zone, 0.4 roe-deer in the second zone and less than 0.2 in the third zome. These differences in the density explain to some extent the effect of discussed factors on the distribution and numbers of field roe-deer in particular zones.

The third zone shows a relatively low numbers of field roe-deer and occurs irregularly as isolated islands. In most cases only one or two isolated neighbouring districts are inhabited by this ecotype. It should be mentioned that districts Przemyśl (Rzeszów Province), Chełm Lubelski and Tomaszów Lubelski (Lublin Province) represent the stands of field roe-deer most advanced in eastern direction.

In the period covered by the inquiry the studied populations of field roe-deer showed both a rise and decrease of the numbers. The highest increase of the population was found in the third zone which showed the lowest numbers of field roe-deer. The lowest increase was observed in the first zone, and intermediate values in the second zone (Table 1). A considerable fall in the population of field roe-deer occurred in all three zones in the year 1969/70 (Fig. 1) in effect of very unfavourable winter conditions. The highest losses, assuming the data for 1966 as $100 \%$, were observed in the second zone $(29 \%)$, slightly lower in the first zone $(21 \%)$, and the lowest in the third zone (10\%) (Fig. 3).

\section{DISCUSSION}

At present roe-deer lives in various habitats. It occurs in all types of forest, from dry pine forest to wet swamps. Very often it lives in all types of river bank shrubs, willow plantations and small field forests. Open areas of cultivated fields, often differentiated in respect of soil, are also suitable for roe-deer. It lives on both not very fertile and rather dry soils of Poznan Province and heavy soils situated at the depressed region of Żuławy in Gdańsk Province. Hence the species found in so different environmental conditions is not easy to be classified within particular populations into definite ecological forms. At present two ecological forms: "forest « and "field « roe-deer are of primary importance for hunting economy (Pielowski, 1970). The formation of the field ecotype has been mainly affected by two factors: population pressure and periodical lack of food ( $\mathrm{Pi}$ e low ski, 1970). The action fo these two factors is augmented in overcrowded populations. Such populations of roe-deer were formed in forests due to a small utilization of animals, elimination of large predators, and supplementation of food during severe winters. Lack of suitable food at certain seasons caused migration of 
some individuals. Prolonged effects of these factors on the overcrowded forest populations resulted in permanent living of some roe-deer in field habitats. Hence the spreading of the field roe-deer in Poland has a different course in comparison with typically expansive species such as Nyctereutes procionoides ( $\mathrm{Now}$ a k \& P i e low ski, 1964) or raven (D o b r ow ols ki et al. 1972).

The occurence and numbers of field roe-deer in particular parts of Poland seem to depend on forestage, agriculture and climate. The collected data indicate that high forestage, divided fields of small farms, and climate of the continental type limit or entirely prevent the occurrence of field roe-deer. The only exception is provided by a few isolated stands of field roe-deer in Eastern Poland.

Field roe-deer causes only small damages to rural economy. Even at high densities of these animals reaching 10 individuals per 100 ha the damages are tolerable from the point of economy (Pielow ski, 1970). . This is very important and should be taken into consideration during planning and further breeding of field roe-deer. Limited harmfulness and rather large breeding potential place field roe-deer among species of primary importance for contemporary hunting. Spontaneous occupation of field areas by roe-deer is too slow a process in comparison with present hunting demands. This process can be hastened by introduction of field roe-deer into these regions of Poland where at present is lacking, and where environmental conditions are favourable for such a breeding measure.

Acknowledgements: The author wishes to thank Dr. Z. Pielowski for generous help during collection and elaboration of the materials. Sincere thanks are also due to all District Hunting Councils for providing information.

\section{REFERENCES}

1. B ła szyk H., 1968: Zarys geografii leśnictwa. Skrypt Wyż. Szkoły Rol. Dział Wyd.: 1-131. Poznań.

2. Dobrowolski K., Pielowski Z., Pinowski J. \& Wasilewski A., 1962: Das Yorkommen des Kolkraben (Corvus c. corax L.) in Polen im Zusammenhang mit seinem Areals und Quantitätsveränderungen in Mitteleuropa. Ekol. pol. A 10, 14: 1-82.

3. D z i ęg i el ewski S., 1965: Nowe spostrzeżenia w sprawie hodowli sarn. Zach. Por. łow., 1(6): 3-12; 3(6): 3-9.

4. H a ber A., 1961: Gospodarstwo Łowieckie. Państw. Wyd. Nauk.: 1-363. Warszawa.

5. Kałuziński J. \& Pielowski Z., 1970: Sarna „polna” zagadnienie nadal aktualne. Łowiec pol., (1377): 2-3.

6. Müller-Using D., 1957: Die Entwicklung der Grosstierbestände in den Kulturlandschaften Mitteleuropas in Verlauf der letzten 100 Jahre. Z. Jagdwiss. 4, 4: 219-225. 
7. Meisnerowski S., 1966: Sarna „polna” w lowiskach Wielkopolski. Łowiec pol. 13 (1112): 6-7.

8. Nowak E. \& Pielowski Z., 1964: Die Verbreitung des Marderhundes in Polen im Zusammenhang mit seiner Einbürgerung und Ausbreitung in Europa. Acta theriol. 9, 7: 81-110.

9. Pielowski Z., 1969: Zagadnienie sarny „polnej” w Polsce. Łowiec pol. 9 (1348): $4-5$.

10. Pielowski Z., 1970: Sarna - Monografia Przyrodniczo Łowiecka Państw. Wyd. Rolnicze i Leśne: 1-120. Warszawa.

11. Rocznik Statystyczny Rolnictwa, 1971. Warszawa.

12. Schmuck A., 1969: Meteorologia i klimatologia dla wyższych szkół rolniczych. Państw. Wyd. Nauk.: 1-316. Warszawa.

13. Szczerbiński W., 1962: Łowiectwo, podstawy ekologiczne. Wyż. Szkoła Roln.: 1-223. Poznań.

14. Szczerbiński W., 1964: Kilka zagadnień nowoczesnego łowiectwa. Skrypt Wyż. Szkoły Rol. Dział Wyd.: 1-136. Poznań.

Accepted, February 10, 1974.

Polish Hunting Association,

Research Station,

64-020 Czempiń, Poland.

Jan KA£UZIN̂SKI

WYSTEPPOWANIE I ROZMIESZCZENIE SARNY „POLNEJ” W POLSCE

\section{Streszczenie}

Materiały dotyczące rozmieszczenia i liczebności sarny „polnej” w Polsce (Tab. 1, Ryc. 2) zebrane zostały drogą rozesłanej ankiety do Powiatowych Rad Łowieckich. Badaniem objęto stan sarn „polnych” w latach 1966-1970 na terenie całego kraju.

Na podstawie rozmieszczenia i liczebności sarny „polnej” autor stwierdza, że występuje ona na obszarze całego kraju za wyjątkiem woj. białostockiego. Są jednak zasadnicze różnice dotyczące rozmieszczenia i liczebności tego ekotypu sarny w poszczególnych rejonach kraju. Na tej podstawie obszar Polski podzielono na cztery strefy: $1-$ gdzie występuje najwyższe zagęszczenie tego ekotypu, $2-\mathrm{z}$ mniejszą ilością stanowisk i niższą liczebnością, $3-\mathrm{z}$ pojedynczymi i wyspowymi stanowiskami sarny „polnej”, 4 - sarna „polna” nie występuje. Rozmieszczenie i liczebność sarny „polnej” na terenie Polski obrazuje Ryc. 2, Tab. 1.

Analizując zebrany materiał autor dochodzi do wniosku, że na rozmieszczenie i zarazem liczebność sarn „polnych" zasadniczy wpływ wywierają trzy czynniki: lesistość, struktura agrarna i klimat. 